
and download for private research and study only. Not for re-distribution, re-sale or use in derivative works. (C) SOAS, University of London 2018.

\title{
Diplomatic Translation and the Professional Selves of Mercer Cook ${ }^{1}$
}

\author{
Aedín Ní Loingsigh
}

\begin{abstract}
:
This article explores the ways in which African American Mercer Cook's translation practice reflects complex overlaps between his professional/personal selves and an ideological backdrop that encompasses black internationalism, U.S. race struggles and mid twentiethcentury diplomatic relations with Africa. A first section explores how Cook, a university professor of French, uses what he terms the "close-to-home" value of translation in order to expose his African American students to what has been written about them in French. At the same time, translation is seen by him as essential to building a "shared elsewhere" where his students can reflect on their place within a black world that is neither nation-bound nor monolingual. A second section examines the way in which Cook's translation practice is inflected by his role as U.S. ambassador in francophone West Africa during the 1960s. In this context, the convergence of U.S. civil rights with official U.S. Cold War policy on post-colonial African states War is key to understanding Cook 'stance' as a translator and the way in which he seeks diplomatically to propel his translations of L.S Senghor's texts towards a racially riven US readership.
\end{abstract}

Key words: diplomatic translation; black internationalism; French Studies; Mercer Cook translator 'stance'

\section{Introduction}

Moradewun Adejunmobi observes that "the power to avoid translation and thus foreign languages is one of the privileges extended to individuals who are monolingual in powerful languages". As an example, she cites "Americans who are monolingual in English" and "view the act of translating as labor reserved for polyglot immigrants" (Adejunmobi 2014: 166). Adejunmobi's comments are framed within the context of contemporary multilingual African societies. They are an important reminder of the unequal cultural trade on which African-related translation activity is often based, particularly when transmission involves the persistently influential languages of former colonial powers. Her focus on the issue of Nigerian audio-visual translation in

\footnotetext{
${ }^{1}$ A significant amount of research for this article was conducted at the Moorland Springarn Archive, Howard University, Washington D.C. which holds Mercer Cook's personal papers. I am grateful to Stirling University's Division of Literature and Languages for financial assistance to support this visit. I also wish to express my appreciation for the invaluable assistance provided there by archivist Sonja J. Woods. Unless otherwise stated, all parenthetical references to Cook's personal papers in the main body of the text begin with his initials (MC) followed by the relevant box and file number.
} 
vernacular languages also underlines the urgent need for translation studies to move forward onto under-explored cultural and linguistic terrains within the continent. However, pace Adejunmobi, the example proposed by her above to illustrate general African-related translation issues will be used here to shift discussion of translation more firmly onto the diasporic context of the United States and the mid twentieth-century approach to translation of African American Mercer Cook. From Adejunmobi's characterization, it is possible to infer that the translator in a U.S. context is a marginalized figure engaged in undervalued, and passive, if not servile labour. Cook's example, however, reminds us that Adejunmobi's image of monolingual anglophone America requires greater nuance and historical depth if it is to account for the relevance of the 'colour line' and the ways in which this persistent dimension of U.S. culture demand that assumptions concerning the so-called privilege of monolingualism and the passivity of translation be reassessed.

Who was Mercer Cook? His peers included cultural icons of the New Negro Movement and the Harlem Renaissance such as fellow African Americans Alain Locke and Langston Hughes and the Jamaican Claude McKay. Lauded for their creative achievements, these figures are also remembered for their contribution to the internationalization of a black identity forged in exchanges with Africans and others of African descent in cosmopolitan interwar Paris. As a student of French, and later a university professor of the language, Cook was present in the French capital at different moments during this heady period and during the prelude to African independence. Here, he also crossed paths with other arbiters of black transnational culture such as future Senegalese poet-president Léopold S. Senghor, francophone Caribbean authors Léon Gontran Damas and René Maran, Présence Africaine editor Alioune Diop and Martinican sisters Paulette and Jane Nardal, who were key figures in developing contacts between African Americans and black francophone thinkers. The Faculty File for 
Romance Languages held in the Moorland Springarn Archive of Howard University, Washington D.C., where Cook spent most of his academic career, notes his efforts in the recruitment of visiting francophone staff during the 1930s. Amongst these were the Haitian historian and diplomat Dantès Bellegarde, the latter's compatriot, politician Lucien Hibbert, and Martinican Louis T. Achille, cousin of the Nardal sisters. During the 1940s, a period as supervisor of a US-sponsored English teaching project in Haiti further consolidated the international nature of Cook's experiences and insights and may well have played a part in his 1961 nomination as U.S. ambassador to Niger and, in 1964, his nomination as ambassador to Senegal.

By any standard, Cook's professional trajectory was highly distinguished. Born in Washington D.C. in 1903 to renowned African American musicians and performers Will Marion Cook and Abbie Mitchell, Cook was clearly a product of an African American middle class that, from the era of the New Negro, succeeded in finding a way onto distinguished literary, academic and political stages. Recovering and analysing Cook's contribution with the seriousness it deserves is not straightforward, however. First, constructing a coherent biography involves identifying the ways in which his different professional identities as academic and diplomat feed into each other. In a related way, this means tracing the nomadic nature of Cook's experience as it moves around the “'common' 'elsewhere[s]'” (Edwards 2003: 23) of the black French-speaking world at a pivotal moment in history. Understanding who Cook was and what he achieved also requires an appreciation of the complex intersection between Cook's professional selves and his racial self. Indeed, his low-key, or what might be termed his "diplomatic" negotiation of the external realities and conflicts that unquestionably shaped his different selves may well have contributed to Cook's marginalization in accounts of the intellectual and cultural movement he undoubtedly helped to shape. 
It is at this juncture that translation and its uses in Cook's career come into play. Finding Cook, and explaining who he was and what he did requires a model of translation that is sensitive to the ways in which this practice can make the translator indispensable at particular historical moments at the same time as the role of this figure risks becoming obscured by the very weight and complexity of that history. As a university professor of French and a diplomat who had attained a high level of fluency in that language, it is inevitable that Cook translated according to the widespread understanding of this practice as the linguistic transformation of a source text to a target text. No proof is needed to surmise that, as a young student of a foreign language himself (in Washington's Dunbar High School and subsequently Amherst and Brown Universities), he was required to translate in order to develop linguistic mastery. As an academic, Cook was clearly dedicated to the discipline of French Studies that bookended his diplomatic career, and, through his practices of translation and anthologization, made sure that black scholars and students had at their disposal texts that made French language and culture relevant to them. In a first section devoted to texts published by him during the early years of his teaching and research career, this article explores the place Cook's academic self attributes to the pedagogical value of translation. Here, the African American context of much of Cook's academic life is vital for understanding the ways in which he saw translation transnationalizing his scholarly discipline and reinforcing a shared, interlingual identity amongst black learners of French and English.

A second section turns to Cook's diplomatic self, or what might be broadly understood as an official but underexplored context of black internationalism. Here, again, translation and the insights it bestows, are key. Cook's private correspondence, as well as an interview he gave some years before his death in 1987 (Njiiri 1981), make clear that longstanding friendships and affinities with francophone Africans underpinned the 
diplomatic ties he sought to establish between the US and newly independent Niger and Senegal during his time spent as an ambassador in those countries (1961-1966). Although Cook later translated Cheikh Anta Diop's The African Origin of Civilization (1974) and a novel by Guinean Thiam Djibi (1981), the focus here is on his 1964 translation for a U.S. target readership of political essays by Senegalese president, Léopold S. Senghor. Examining paratextual and contextual evidence connected to this translation, it is clear that what Maria Tymoczko terms "the stance" (2010: 216) of the translator, or their place of enunciation in relation to what they are translating and for whom, is particularly knotty where Cook is concerned. The haziness of Cook's "stance" is further compounded by what is termed here his "diplomatic" approach to translation. Cook's academic-related publications already reveal that he is disinclined to make overt political statements, However, nobody with Cook's background or experience could ignore the race-related politics of his time and, whatever the diplomatic distance or even objectivity he may wish to convey, his choices of text are themselves a first indication of the grounding of his practice, and his selves, in the ideologies and conflicts of the times in which he lived. The challenge here is to determine how and when that reality intrudes into his work and how Cook's 'selves' deal with any resulting struggles.

\section{The academic self and translation}

Translation viewed as a pedagogical pillar of language learning and teaching is evident in publications from the earliest days of Cook's career as teacher and scholar. An example is Le Noir, his anthology of twenty-nine Frenchlanguage authors expressly aimed at African American classrooms and students who are "attempting to master [...] the intricacies [...] of this beautiful foreign tongue" (Cook 1934: vi). Original extracts from writings by literary luminaries such as Montesquieu, Voltaire, Tocqueville, Balzac are 
included, and the collection concludes with targeted comprehension and translation exercises. In 1936, Cook collaborated with Guichard Parris to coedit a version in the original French of Madame de Duras's Ourika. This nineteenth-century novella is a tragic depiction of a young Senegalese girl rescued from slavery and given a white education in an aristocratic French household. At the age of twelve, a traumatic awakening of racial consciousness causes Ourika to realize that she is 'unfit' for the life which her white family can take for granted. Although marshalled at the time of its publication for the abolitionist cause, the text is now widely agreed to be ideologically contradictory in its depiction of racial difference (see for example Miller 2007; Prasad 2009). The Cook-Parris edition, published in the "French Series" at Atlanta University, the historically black institution where Cook taught briefly, is presented in its title pages as "being for $2^{\text {nd }}$ year French classes". At the end of the novella, a list of vocabulary deemed challenging or noteworthy is provided with translations. In addition, footnotes draw attention to specific grammatical, lexical and stylistic difficulties that students are likely to encounter as they themselves translate the text, an activity implied by Cook and Parris to be an integral part of the process of engaging with foreign-language literature. Students are advised, for example, not to translate a pleonastic "ne" or a euphonic "l", difficult-totranslate vocabulary is highlighted and there are explanations of inversions that may confuse learners.

A similar pedagogical use of translation is evident in another publication from 1944 where the teaching and scholarly activities of Cook's academic self unmistakably come to the fore. In the mid-1940s, Cook had been appointed to a 22-month post as supervisor of an English-language teaching project in Haiti sponsored by the US Office of Education. The Haitian-American Anthology: Haitian Readings from American Authors, compiled and edited in collaboration with Dantès Bellegarde, is clearly 
inspired by this experience and is presented as both a learning tool and a teaching resource. Here, again, language students (this time Haitian learners of English) are encouraged to practise their skills of linguistic translation through a series of exercises based on source-language texts.

To deduce from the above publications that Cook viewed translation purely as a decontextualized tool for acquiring linguistic competence would be misleading, however. The content of these texts, and the choices revealed through processes of editing and anthologization, show that Cook's understanding of translation requires considerably more complication. For one thing, he appears to be encouraging his black American students to understand translation as a complex form of reflection. Notably, the two earliest teaching-focused publications, Ourika and Le Noir, present white-authored source texts foregrounding perceptions of blackness. Thus, when Cook's African American students of French overcome linguistic difference by translating Claire de Duras's source text they are nonetheless returned to realities that need no translation: white racist thinking and the Duboisian awakening of a black double consciousness. Interestingly, however, whereas Cook and Parris support the student in the practical task of translation, they do not use their editorial interventions in Ourika to guide the student through any epistemological issues that might arise from engagement with the text. Instead, once the language shock of the French has been overcome, and the historical context of nineteenth-century France is then read in the African American present, it is left to the student-translator to make sense of the fact that the cultural difference revealed by their own translation contains a racist reflection of themselves that is all too familiar.

In the introduction to Le Noir (1934), however, Cook feels that translation's uncovering of racism as a shared historical condition warrants clearer explanation of this anthology's environment of reception: a racially segregated United States. He states that students "in the classes of our 
colored schools [...] have a right to know what Maupassant, Daudet, Hugo, and Mérimée had to say about the Negro" (Cook 1934: vi) before evoking the canonical white critic, Sainte-Beuve, to argue that "no question was insignificant or unimportant in the study of a great personage" (Cook 1934: vii). Inferring strongly that the question he is raising in Le Noir relates to evidence of racist views in some of his chosen authors, Cook claims that "the answer to that question will, in a number of instances, be helpful in determining the character" (Cook 1934: vii). In this respect, no punches are pulled with the extract provided from Balzac's Le Père Goriot. Here, the cynical Vautrin is shown expressing a desire to become a slave owner in the southern United States. In a departure from the usually diplomatically cautious approach to be found in Cook's many allographic prefaces and footnotes, he is clear that "Vautrin [...] is a villain who expresses many of the personal views of the author [...]. Judging from Balzac's general philosophy [...] and the majority of his references to the Negro, these words may indeed be considered as indicative of his conception of the race" (Cook 1934: 41).

Quoting Gerald Early, Brent Hayes Edwards, highlights "a considerable obsession in anthologizing the Negro" amongst African American intellectuals and writers of the 1920s and 30s (2003: 43). Cook's anthologies, and indeed his translations, certainly fit with the trend described by Edwards of "researching, notating, transcribing, assembling, and packaging almost anything having to do with populations of African descent" (Edwards 2003: 44). Similar to the New Negro anthology as presented by Edwards, Cook's early publications can be said to "fram[e] race" and are also "a way of accounting for a given cultural conjuncture. [They delimit] the borders of an expressive mode or field, determining its beginning and end points, its local or global resonance, its communities of participants and audiences" (Edwards 2003: 44). However, whereas demonstrating the "intellectual parity of the Negro" with white American culture is identified by 
Edwards (Edwards 2003: 46) as the key objective of anthologies such as James Weldon Johnson's 1922 Anthology of American Negro Poetry, Cook's anthologizing philosophy, whilst clearly related to this approach, seems more constitutive of efforts to establish a new beginning for the study of French amongst the particular community of African American students and teachers of this language. Thus, Cook's particular zeal for anthologization is better understood as overlapping with the practice of an "agent of translation", a figure defined by John Milton and Paul F. Bandia as one who "devotes great amounts of energy [...] to the cause of a foreign literature, author or literary school, translating, writing articles, teaching and dissemination of knowledge and culture" (2009: 1). Moreover, in promoting engagement with a different culture through knowledge of its language, Cook is perhaps also suggesting that the privileges accrued from monolingualism in a North American context are not available to African Americans. Cook's perception of French as an internationally black language provides an additional benefit in that knowledge of it will help to provide new scripts for an international definition of blackness.

Used by Cook, then, translation and anthologization - and the collaborative approach that often characterizes his practice of these activities - become first a means to promote canonical French literature but in a way that is simultaneously shaping a racially aware approach to it. The texts he selects and the prefaces he writes underline an opposition to any camouflaging of racism in the presentation of this literary culture to language learners. This is significant because Cook's politics can often appear to be moderate, or, as one critic has it, "detached" (Rideout 1968: vi), as when he claims in a later publication on Five Negro Authors that "the French have never stressed color as have the Americans, and an occasional French author with some Negro blood in his veins has been accepted as white" (Cook 1943: xi). I return below to possible explanations for the diplomatic position of 
Cook's professional selves. In the meantime, however, it is possible to argue that this particular stance on French literary culture does suggest an interesting divergence of opinion from contemporaries who viewed France as a racist-free sanctuary for African Americans (see Edwards 2003: 6). It seems to explain why Cook insists in Le Noir that the "classics" of seventeenth-century theatre and other long-established "favourites" (Cook 1934: vi) of American language-learning classrooms be retained but presented "from a different point of view". Black students, he argues, must "know what has been written concerning them in this beautiful foreign tongue" (Cook 1934: vi).

That said, Cook's critical re-reading of canonical texts in these earliest publications does not extend to advocating for their removal and replacement by works written by non-white authors. Nor is his diplomatically subversive strategy sufficiently elucidated and contextualized in the prefaces and footnotes that frame his choices. Consequently, translation risks becoming an alienating experience for Cook's black translator-student, potentially forestalling the journey towards a language and a culture where an initial foreignness can seem familiarly hostile.

Three publications edited by him in the 1940s and 50s, however, differ in focus and objective and suggest a development in his thinking. These selections of largely black-authored texts demonstrate a more outwardreaching use of translation that seeks to connect black language learners with a "common elsewhere". Interestingly, Five Negro Authors (1943) breaks somewhat with the practice of anthologizing source texts seen above. It takes the form of scholarly essays that introduce "colored Frenchmen of Letters" about whom American ignorance is "understandable" given that "few French Negroes have been translated into English", and, where they have, as in the case of René Maran, have seen their "motives and even [their] words [...] misconstrued" (Cook 1943: xi). The above-mentioned Haitian-American 
Anthology (1944) compiled with Dantès Bellegarde is a collection of Englishlanguage texts with exercises for advanced learners. The selection of translated writing by Haitians in An Introduction to Haiti (1951) appears to have been compiled to accompany a Washington exhibition dedicated to the bicentennial of Port-au-Prince's founding.

Despite differences in format, however, all three publications overwhelmingly present translation as a means of opening up conversations between students and readers who are learning about their place in a shared transnational black history. Thus, in reading and translating "The Miracle of Haiti" by Frederick Douglass and "God and the Pintards" by Zora Neale Hurston, to mention some of the African Americans who constitute the majority of authors featured in The Haitian-American Anthology, "young Haitian students will not encounter the vicious, sensational comments which have characterized the superficial works that many Americans have written about Haiti. On the contrary, they will find that Lincoln's compatriots have sometimes discussed this Republic with sympathetic understanding" (Cook and Bellegarde 1944: vii). (A further nuance in Cook's practice of anthologization can be perceived in the targeting of The Haitian-American Anthology to a young student readership. It suggests a useful comparison with the educational primer and this form's uses of literature for instilling moral, and later political values in young readers through carefully chosen examples (for a general overview of educational primers in a US context see Sánchez-Eppler 2005). Shifted to the "black" contexts of Cook's collection here, comparison with the possible worlds opened up by the primer immediately evokes the historical outlawing of slave literacy but also recalls a powerful example from African American history: the impact of the Columbian Orator on Frederick Douglass. Yet, whereas Douglass (1845) in chapter 7 of his autobiography describes the "anguish" he felt when reading the insight this primer gave him of "[his] condition, without the remedy", 
Cook clearly wants his anthology to provide young readers with a sense of solidarity that translates across languages and national boundaries and suggests new futures.)

Five Negro Authors is most likely also intended to make African American students of French feel at home in an equally inclusive history of French letters. Nonetheless, in privileging this particular place in history of his five authors, Cook reveals yet again the unwillingness to sound anything other than a moderate note to his thinking. Thus, when he argues that Julien Raimond, Charles Bissette, Alexandre Dumas, Auguste Lacaussade and René Maran's "place in Negro history is less debatable than their place in literature" (Cook 1943: xii), he appears to be negatively juxtaposing their literary output against a standard of quality that is taken for granted in collections introducing white authors.

In the transcript of the interview conducted in 1981 with Ruth S Njiiri, an elderly Cook reflects back upon his reasons for embarking on an academic career in French: "I wanted something I could use as a handle to interest more of our black students [...] in people of their background who used the language (1981)." He goes on to elaborate by explaining the development of his own research interests, beginning with his $1936 \mathrm{PhD}$ thesis on "French Travelers in the United States between 1840 and 1870":

Through the years, I worked first of all on what the white Frenchman had written about blacks and then... as others, then René Maran appeared on the scene, I made it a point to find out what they were writing that I could pass on to my students in a way to stimulate them and to make them realize that there was a practical close-to-home value in the study of this strange language that I was attempting to teach them. (Njiiri 1981)

Cook's account underlines his belief that the practical value of language learning and translation is as much about developing self-understanding in his black students as it is a means of providing a window onto other cultures. 
The gift of foreign language mastery, and by extension translation, he suggests here, is to understand the self as "the Other's Other" (Porter 1994: 153). However, in the black transnational context that shapes Cook's academic self, language learning and translation cannot be limited to any solipsistic use or one where a "close-to-home value" is closed off from a "shared elsewhere". Rather, translation permits the African American learner of French, or the Haitian learner of English, to move beyond their immediate environment. In these languages, linguistic symbols of their own history of enslavement, black learners can begin to see themselves reflected positively through an international lens. Here they (re)connect with a community where they can be linguistically different yet still find that translation brings them close to another shared black home. As for Cook's academic self, at stake in teaching French and translation is not equipping his African American students with an instrumentalized understanding of another language that will enable them to become passive translators for others. Rather, is about providing them with a sense of discernment and agency in the world through linguistic means:

The responsibility of the foreign language teacher is a heavy one. His (sic) duties transcend the limits of grammar, pronunciation, and vocabulary, though much of his effort will certainly be directed toward the attainment of these three objectives. He must also introduce his pupils to the civilization of the country whose language they are studying. If he wishes, he can develop rabid, chauvinistic isolationists, or internationally-minded men (sic) who can appreciate the best that other nations have produced. He can be a propagandist in the lowest or noblest sense of the word. (Bellegarde and Cook 1944: vii)

\section{The diplomatic self and translation}

To be a diplomat is to engage in transnational communication. To do this effectively requires mastering the 'language of diplomacy', a notion, as 
opposed to a specific language de jure (the paradigm here of course is French), that expresses the subtleties, nuances and nonverbal signals required for meaningful transnational dialogue. And just as translation represents "one of the ways the 'turbine' of the cultures of black internationalism is lubricated" (Edwards 2003: 9), so too does it oil the cogs of diplomacy. In turn, a black presence within the official sphere of diplomacy must also be seen as decisive in establishing and consolidating racial solidarity as well as promoting equality on an international basis. Yet, whereas the role of artistic ambassadors for black identity within an international context has been recognized in influential studies (Stovall 1996; Edwards 2003), the question of representation in the form of official ambassadorship is often neglected or examined within frameworks of national foreign policy.

An African American tradition in international diplomacy dates from the late 1860s and the early 1870s with the appointment of black ministers to Liberia and Haiti (see Teal 2008; Roberts 2013). However, this development did not mark the beginning of a smooth upward trajectory in terms of the numbers of black appointments to official diplomatic roles and studies widely concur that a racial mindset has persistently undermined efforts to build a representative U.S. diplomatic service. Nonetheless, in his study of North American Black Diplomacy, Michael L. Krenn acknowledges that the Kennedy and Johnson administrations "pursued the issue of black employment in foreign service work more vigorously than their predecessors" (1999: 7). He also notes how these relatively more progressive administrations "took many of their African-American diplomatic appointees [...] from the academic world" (Krenn 1999: 125), although he does not elaborate on the appeal of academics for such roles. Krenn does, however, highlight the efforts of Cook's Howard University colleague, history professor Rayford Logan, to influence the appointment of African Americans to high- 
level diplomatic posts during the 1950s. Logan's suggestions of those he saw as well-qualified, competent "Negro" candidates included several fellow academics (Krenn 1999: 23). Krenn also highlights the significance of John H. Morrow's 1959 appointment as the first U.S. ambassador to Guinea under the Eisenhower administration. Like Cook, Morrow was a professor of Modern Languages and is quoted as having impressed with his "knowledge of African affairs and French politics, [his] friendly relations with many Africans, [his] academic record, and [his] fluency in French" (Krenn 1999: 109). Regarding Cook's appointment, Krenn has little to say other than noting in passing that the former "was on leave from Howard and working as director of the African Affairs Program at The Congress for Cultural Freedom in Paris when he was selected" (Krenn 1999: 109).

No documents in Cook's personal archive allow clarification of the circumstances of his ambassadorial appointments. A short 1948 publication by him on Education in Haiti does, however, provide evidence of an early professional connection to the Federal Government. Clearly produced as part of the above-mentioned Haitian teaching project, this study is presented as being the first in a series published by the U.S. Office of Education. According to the introduction by Kendric N. Marshall, Director of International Educational Relations, the series was "designed to promote understanding of educational conditions in the American countries and to encourage cooperation in the field of Inter-American education" (Cook 1948: n.p.). A 1954 article by Cook on "The Negro Spiritual" in France further mentions communication between him and the then U.S. Information Service now Consulate) in Bordeaux regarding a series of concerts in that city for which he served as master of ceremonies. It is now also accepted, of course, that the CIA was covertly funding the above-mentioned Congress for Cultural Freedom where Michael L. Krenn says Cook was on secondment when he was first appointed to the Foreign Service. Whether Cook knew about this 
connection or not, we can conjecture that the anti-communist ideology of this organization would have bolstered his politically representative credentials amongst those assessing his suitability for the role of a U.S. ambassador during the Cold War (cf. Purcell 2013 for more on the Congress for Cultural Freedom). Finally, the 1981 Njiiri interview also provides a vital retrospective reflection by Cook on his official role as a U.S. ambassador. However, yet again Cook is discreet in his discussion of the details of his entry into this field, simply noting that:

\footnotetext{
When a new President came in, the young, vibrant John F. Kennedy, he asked around for [...] blacks who would be recommended for posts in the diplomatic service. And it seems that my name was on lots of the lists, and that's how I got into the Foreign Service. (Njiiri 1981)
}

The question of the specific circumstances surrounding Cook's ambassadorial appointments by Presidents Kennedy and Johnson must, therefore, remain unanswered for now. Nonetheless, it is obvious that during the years of foreign service that constitute our focus here (1961-1966), Cook's translation activities overlap with his diplomatic role. Key here is the figure of Senegalese President Léopold Sédar Senghor and Cook's relationship with him as English-language translator of some of his political writings. Most notably, Cook translated two essays by Senghor that were published in 1962 by Présence africaine as a bilingual edition entitled Nationhood and the African Road to Socialism. These essays were subsequently re-edited together with a third newly-translated essay in the 1964 volume On African Socialism published by Praeger of New York. A detailed comparative analysis of Senghor's source texts and Cook's translations would of course provide important insights into Cook's technique at the level of metrical, lexical and rhetorical choices. Such an approach, for example, allows Michael J. Dash (1978) to identify a small degree of qualitative impoverishment in Cook and Langston Hughes's translation of the creolized French of Jacques Roumain's 
Gouverneurs de la rosée. Here, however, my concern is less with how Cook translates stylistically speaking-or indeed with compiling an exhaustive list of his translations-and more with understanding what his translating practice reveals as it intersects with his racial and professional selves. This approach is informed by Maria Tymoczko's observation that the "ideology of a translation resides not simply in the text translated, but in the voicing and stance of the translator, and in its relevance to the receiving audience" (2010: 216). Consequently, here I focus exclusively on the framing con/texts of his translations of Senghor-his introduction as well as correspondence related to the 1964 Praeger translation-in order to elucidate the ways in which Cook appears to ready his translation of a black African socialist text for reception. In a racially segregated United States that was simultaneously preoccupied with Cold War Politics, Cook appears to conclude that he must proceed with customary diplomacy if he is to avoid the dangers of being seen as "the traitor from within or the agent from without" (Tymoczko 2010: 226).

In the Njiiri interview, Cook explains that he first met Senghor in Paris in 1934. His personal archive at Howard University contains intermittent correspondence with the Senegalese president beginning with a difficult to decipher handwritten letter from the latter sent in 1948. Once again, the overall view provided by Cook's personal papers remains patchy. Nonetheless, correspondence related to the translation and publication of $\mathrm{On}$ African Socialism allows a reasonable picture of the project to be sketched. What emerges clearly in the Cook-Senghor correspondence between 1961 and 1963 (MC box 3, file 5) is general unhappiness regarding the quality of the earlier Présence africaine publication. This appears to stem to a degree from frustration on the part of both men with what Senghor refers to, in a letter dated September 28 1961, as editor Alioune Diop's “absence de méthode" [poor organisation]. On March 21 1963, Cook bemoans the fact that he has been sent three copies of the published Présence africaine version of 
his translation without having seen proofs and despite having submitted the manuscript to Diop nineteen months previously. In a letter dated April 3, 1963, Arnold Dolin of Praeger intervenes directly and writes to Senghor in French explaining that the New York publishers will not be able to use the Présence africaine translation because of inferior printing quality and the number of typographical errors. It is not clear who has instigated the American publication of Senghor's work but Dolin explains that he has approached "l'Ambassadeur Cook" to rework his original Présence africaine translations, translate a new piece and write an introduction for the American edition. Cook is, he explains to Senghor, "l'homme le plus capable de faire une traduction précise et fidèle à vos pensées" [the man most capable of producing a precise translation that is faithful to your thinking]. On April 30, 1963, Dolin writes to let Cook know he is pleased the latter has agreed to the changes.

In certain ways, Cook's brief introduction to On African Socialism resembles a foreign service brief. It offers a straightforward description of the political ideology of newly independent Senegal as shaped by the vision of its singular president and emphasizes the country's ambition to "become a democratic nation state" (Cook in Senghor 1964: vi). The tone of the introduction is itself a model of the ambassador's signature diplomacy, studiously avoiding any controversy in its analysis, and carefully presenting Senghor's qualities in terms that could be said to hew to a Kennedy-like understanding of civic duty. As Cook summarizes, Senghor "offers his nation democracy, peace, and progress, not on the proverbial silver platter, but through persistent, intelligent and concerted effort" (Cook in Senghor 1964: $\mathrm{xv}$ ). And whilst Cook raises the thorny issue of the 1962 attempted coup d'état against Senghor, the latter's bloodless handling of it becomes evidence of the president's "statesmanship" and his country's "attachment to civilized procedures" (Cook in Senghor 1964: xiv). (Intriguingly, no mention is made 
of Mamadou Dia, leading conspirator of the coup and by now imprisoned former prime minister whose African Nations and World Solidarity had been translated by Cook in 1962 and who had been introduced by him in terms remarkably similar to those now being used for Senghor.)

As Sherry Simon reminds us, the translator's preface has historically had a key role in "propel[ling] the work towards new markets and audiences. It seeks above all to capture the goodwill of the public" (1990: 11). In Cook's 1964 preface to On African Socialism we are reminded how Cook's professional selves-translator of black African writing and simultaneously black U.S. ambassador in francophone West Africa-are caught up in the convergence of U.S. civil rights with official U.S. policy on post-colonial African states in the context of the Cold War. Propelling the work towards new U.S. readers in this context requires a complex double act and a "diplomatic" use of translation: Cook must reassure one section of that U.S. readership that Senghor's ideas support their ambitions to achieve the freedom, justice and equality denied to them within the Unites States whilst persuading the other that there is nothing in the poet president's thinking or actions that would align him with America's communist enemies and weaken Senegal's commitment to the values of freedom, justice and equality that the United States believed it represented abroad.

In seeking to "capture the goodwill" of African American readers towards Senghor's work, Cook is careful in his preface, then, to emphasize Senghor's embrace of a transnational perspective of the "Negro world" (Cook in Senghor 1964: xii). More specifically, he highlights the Senegalese president's 'personal contacts with Negroes from the Americas' (Cook in Senghor: xiii) and suggests that the resulting introduction to African American writing constituted a vital influence on Senghor's conception of black identity. Of course, mention of this formative literary encounter for Senghor echoes the very purpose Cook must imagine for his own translation. 
Just as African American acquaintances "complemented Senghor's extensive reading and deepened his respect for the African heritage and his faith in the black man's future" (Cook in Senghor: xiii), Cook seems to suggest that the North American reader (black, but not exclusively so) of his translation of the African Senghor will gain a more meaningful perspective on the struggle for civil rights and the establishment of "a world civilization where blacks, freed from oppression, and whites, freed from prejudice, can cooperate" (Cook in Senghor: xiii).

On the other hand, the previous quote serves as a subtle reminder of how Cook, as an African American diplomat and translator, must juggle the responsibilities of his various selves in a context where a predominantly white-shaped American foreign policy on black Africa intersects with the increasingly febrile nature of his own country's internal racial politics. What is clear from certain contextual documentation is that the U.S. domestic struggle for civil rights is on Cook's mind at the time he is translating Senghor's political essays for American publication. In a letter sent from Niamey on 15 February 1964 (MC Box 3, file 2) to Dr James M. Nabrit, president of Howard University, Cook reveals a desire to return to Washington in an academic role. Michael L. Krenn (cf. 1999, 156-57) suggests that when Cook eventually resigned from the diplomatic service in 1965, it was because of frustration with a racist-related lack of support from the U.S. Foreign Office. Retrospectively, an ever cautious Cook is also ready to broach the relevance of race and racism to his own specific experiences as a diplomat without linking them nearly so unequivocally to his resignation (Njiiri 1981). In the personal letter to Nabrit, however, we can see how awareness of the broader context of internal U.S. politics was clearly shaping his thinking: "With an election coming up, my future plans are somewhat uncertain. At this most critical moment in race relations, I feel that perhaps I should be home." 
Once again, the precise circumstances that caused Cook to postpone this decision and remain in his ambassadorial role for more than a year following the letter to Nabrit remain hazy for the moment. (His role in promoting and supporting the Dakar 1966 Festival mondial des arts nègres, "one of the most unforgettable experiences in my lifetime" he tells Ruth Njiiri (1981), was unquestionably a reason, however (see Murphy 2017 for more on this festival)). If concern about mounting tension over civil rights was the factor it appears to have been, Cook is as ever discreet in his published pronouncements on U.S. internal politics and, other than the geographically non-specific reference to a "world civilization where [...] whites [are] freed from prejudice" (Cook in Senghor 1964: xiii), divulges no personal view on the matter in the paratextual elements of his Senghor translation. As underlined in his 1981 interview with Ruth Njiiri, Cook was more than aware of the racism of a U.S. foreign service whose "values" he was nonetheless representing abroad as an ambassador (his interview also shows that he was highly aware of the racism experienced by African diplomats in the United States). It is also easy to surmise that he knew how the foreign policy elite in Washington "discounted, attacked, ignored, and tried to suppress what they perceived as more 'radical' voices among African-Americans" and consequently found "relatively 'moderate' voices from the black community [...] more acceptable" (Krenn 1999: 6). Moreover, his diplomatic self would also have been keenly aware of the need to advocate fairly for Africans with whom his "racial" self also felt a deep affinity. At the same time, his introduction to On African Socialism aims to reassure a certain white American constituency that Senghor's thinking transcends race-based allegiances in its desire for racial cooperation.

One particular moment in Cook's interview with Njiiri underlines this complex intertwining of Cook's professional and racial selves. Speaking of his frustration with the Foreign Office over the inability to secure aid and his 
decision to resign, he explains: "I felt that this was setting a bad precedent for future black ambassadors [...] because there had been this question in the beginning: Can a black U.S. ambassador get the assistance that these countries need?" (Njiiri 1981). This admission suggests that an objective behind the diplomatic voice used by Cook the translator is to enable Senegal to get the assistance it needs. If he is to win over the goodwill of an influential American readership, Cook must highlight Senghor's political fitness and make an argument for the compatibility of Senegalese socialism with American democratic values (just as he had done in his translation of Mamadou Dia). This would explain the matter-of-fact reassurance in his U.S.targeted translation that the socialist Senghor is not a threat, and specifically not a red threat, as the latter is said to believe that "Senegal must pursue a policy of non-alignment to avoid involvement in the Cold War" (Cook in Senghor 1964: vii)—see Duignan and Gann (1984) for the very real economic costs to post-colonial African nations who were seen as hostile to the United States. At the same time, Cook, as translator must remain purposefully neutral with regard to his own political commitments: to return to Maria Tymoczko's formulation mentioned above, it is the only way he will not be condemned as "the traitor from within or the agent from without". In the end, however, doubts must remain regarding the effectiveness of this diplomatic translation given that, by Cook's admission, U.S. funding to Senegal decreased dramatically during his tenure as ambassador.

\section{Conclusion}

It is not easy to do justice to Mercer Cook's life and work in a context such as the present one. In addition to focusing discussion on specific types of texts in the first section and to translations produced during Cook's diplomatic career in the second, the approach here has been to work around gaps and 
silences in Cook's biography. It is clear that a fuller account will only be accomplished when relevant archives have been fully exploited. Yet beyond the necessity for a continued search for Mercer Cook amongst such sources, this article has also pointed towards the usefulness of developing a critical understanding of his approach to translation that might better explain how he fits in with the political and ideological developments of his time and why this role is not always given the recognition it deserves. For even if Cook is acknowledged on the front covers, title pages and prefaces of his translations, he tends to be a footnoted figure in studies of the period that shaped, and was shaped by, his practice of translation. In Cook's case, lack of insight concerning who he was and, more importantly, what he thought, remains hidden behind the studious diplomacy of his own particular approach to translation. This makes it difficult to position him alongside better-known, more outspoken and radical contemporaries. The risk here is also that a view of Cook as an aloof translator develops, one that presents him as a neutral inbetween figure with no strong ideological allegiances. Yet, even if it is impossible to retrofit Cook as a radical, a focus on his diplomatic translation begins to open up a more complex picture: it reveals an academic who understood the radical possibility of using translation to change the narrow, national perspective of African Americans on their own identity and history; it brings to light a diplomat who understood that translation was a means for black voices to be heard in the international spheres from which they had been excluded. For that reason, it is precisely on the knotty terrain where translation, identity and ideology intersect that the contribution of Mercer Cook, African American French-speaking scholar, teacher, translator and diplomat, must continue to be explored.

\section{References}




\section{Publications by Mercer Cook}

Cook, Mercer. 1934. Le Noir. Morceaux choisis de 29 Français célèbres. New York: American Book Company.

Cook, Mercer and Guichard Parris. 1936. Ourika. Atlanta, GA: The Atlanta University French Series.

Cook, Mercer. 1943. Five Negro Authors. Washington, DC: Associated Publishers.

Cook, Mercer and Dantès Bellegarde. 1944. The Haitian-American Anthology: Haitian Readings from American Authors. Porte-au-Prince: Imprimerie de l'État.

Cook, Mercer. 1948. Education in Haiti. Washington, DC: U.S. Office of Education.

Cook, Mercer. 1951. An Introduction to Haiti. Washington, DC: Pan American Union.

Cook, Mercer. 1954. "The Negro Spiritual goes to France”, Music Educators Journal 40.5: 42-48.

Cook, Mercer and Stephen Henderson. 1969. The Militant Black Writer in Africa and the United States. Madison: University of Wisconsin Press.

\section{Translations by Mercer Cook}

Dia, Mamadou. 1962. The African Nations and World Solidarity, transl. by Mercer Cook. London: Thames and Hudson.

Diop, Cheikh Anta.1974. The African Origin of Civilization. Myth or Reality, edited and translated by Mercer Cook. Westport, CT: Lawrence Hill.

Senghor, Léopold Sédar.1964. On African Socialism, translated and with an introduction by Mercer Cook. New York: Praeger.

Thiam, Djibi. 1981. My Sister, the Panther. New York: Dodd, Mead.

NB :gouverneurs de la Rosé 


\section{Other works referenced}

Adejunmobi, Moradewun. 2014. "Vernacular Monolingualism and Translation in West African Popular Film", in Paul F. Bandia (ed), Writing and Translating Francophone Discourse: Africa, the Caribbean, Diaspora. Amsterdam: Rodopi, pp. 167-87.

Anon. February 1938. "Books by Negro Authors in 1937: Paragraph Reviews for the Guidance of Crisis Readers". The Crisis, pp.47-48.

Edwards, Brent Hayes. 2003. The Practice of Diaspora: Literature, Translation, and the Rise of Black Internationalism. Cambridge, MA: Harvard University Press.

Dash, Michael J. 1978. "Introduction" to $2^{\text {nd }}$ edition of Jacques Roumain's Masters of the Dew, trans. Langston Hughes and Mercer Cook. Portsmouth, NH: Heinemann, pp. 5-21.

Douglass, Frederick. 1845. Narrative of the Life of Frederick Douglass, An American Slave. Written by Himself. Boston: Anti-Slavery Office. Available at https://www.gutenberg.org/files/23/23-h/23-h.htm link2HCH0007 (last accessed 7.07.17).

Duignan, Peter and L. H. Gann. 1984. The United States and Africa: A History. Cambridge: Cambridge University Press.

Krenn, Michael L. 1999. Black Diplomacy: African Americans and the State Department. New York: M.E. Sharpe.

Miller, Christopher. 2007. The French Atlantic Triangle: Literature and Culture of the Slave Trade. Durham, NC: Duke University Press.

Milton, John and Paul F. Bandia (2009). "Introduction: Agents of Translation and Translation Studies", in John Milton and Paul F. Bandia (eds), Agents of Translation. Amsterdam: John Benjamins, pp.1-18.

Murphy, David, ed. 2017. The First World Festival of Negro Arts, Dakar 1966: Contexts and Legacies. Liverpool: Liverpool University Press. 
Njiiri, Ruth Stutts. 1981. "Interview with Ambassador Mercer Cook. PhelpsStokes Fund's Oral History Project on Former Black Chiefs of Mission". Available at http://www.adst.org/OH TOCs/Cook, Mercer.toc.pdf (last accessed 26.02.17).

Porter, Dennis. 1994. "Orientalism and its Problems", in Patrick Williams and Laura Chrisman (eds), Colonial Discourse and Post-Colonial Theory. Hemel Hempstead: Harvester Wheatsheaf, pp.150-61.

Prasad, Pratima. 2009. Colonialism, Race, and the French Romantic Imagination. London/New York: Routledge.

Purcell, Richard. 2013. Race, Ralph Ellison and American Cold War Intellectual Culture. London: Palgrave Macmillan.

Rideout, W.B. 1969. "Foreword”, in Mercer Cook and Stephen E. Henderson, The Militant Black Writer in Africa and the United States. Madison: University of Wisconsin Press, pp. v-X.

Roberts, Brian Russell. 2013. Artistic Ambassadors: Literary and International Representation of the New Negro Era. Charlottesville: University of Virginia Press.

Sánchez-Eppler, Karen. 2005. Dependent States: The Child's Part in Nineteenth-Century American Culture. Chicago: University of Chicago Press.

Simon, Sherry. 1990. "Translating the Will to Knowledge: Prefaces and Canadian Literary Politics", in Susan Bassnett and André Lefevere (eds), Translation, History \& Culture. London: Pinter, pp. 110-17.

Teal, Christopher. 2008. Hero of Hispaniola: America's First Black Diplomat, Ebenezer D. Bassett. Westport, CT: Praeger.

Tymoczko, Maria. 2010. "Ideology and the Position of the Translator: In what Sense is a Translator 'in between'”, in Mona Baker (ed), Critical Readings in Translation Studies. London/New York: Routledge, pp.21328. 
Stovall, Tyler. 1996. Paris Noir: African Americans in the City of Light. Boston, MA: Houghton Mifflin. 